A C T A C H E I C A S C A N D I N A V I C A 27 (1973) $814-822$

\title{
Refinement of the Crystal Structure of Thenardite, $\mathrm{Na}_{2} \mathrm{SO}_{4}(\mathrm{~V})$
}

\author{
A N D ERS G. NORD \\ Institute of Inorganic and Physical Chemistry, University of Stockholm, \\ Box 6801, S.113 86 Stockholm, Sweden
}

\begin{abstract}
The crystal structure of thenardite, $\mathrm{Na}_{2} \mathrm{SO}_{4}(\mathrm{~V})$, has been analysed and refined by the method of least squares on the basis of threedimensional X-ray diffractometer data down to a final $R$ value of $3.6 \%$ for about 800 independent reflections. At $25^{\circ} \mathrm{C}$ the orthorhombic $(F d d d)$ unit cell has the dimensions $a=5.8596, b=12.3044, c=9.8170 \AA$. The investigation has confirmed the general features of the atomic arrangement reported in 1932 by Zachariasen and Ziegler. The crystal structure may be described in terms of distorted $\mathrm{NaO}_{6}$ octahedra and nearly regular $\mathrm{SO}_{4}$ tetrahedra. All $\mathrm{S}-\mathrm{O}$ distances in these are $1.476 \pm 0.001 \AA$.
\end{abstract}

$T_{t}$ his investigation was performed in order to elucidate the size and configuration of the sulphate ion as precisely as possible. For this reason the thenardite phase is convenient since all $\mathrm{S}-\mathrm{O}$ distances are equal due to the space group $(F d d d)$ where the sulphur atom is fixed in a special point position with 222 point symmetry. Moreover, it is interesting to compare the regularity and dimensions of the sulphate ion in different sulphates.

The phase diagram of sodium sulphate shows some very interesting features. According to Gmelin ${ }^{1}$ there are eight different anhydrous phases of sodium sulphate. The crystallographic data of most of these phases are quite unsatisfactory and insufficient. The phase $\mathrm{Na}_{2} \mathrm{SO}_{4}(\mathrm{~V})$ is usually called thenardite after the mineral. It is reported to be stable between $32^{\circ} \mathrm{C}$ and about $180^{\circ} \mathrm{C} .1$ It seems that the presence of traces of $\mathrm{H}_{2} \mathrm{O}$ in inclusions changes the conditions for the stability of thenardite. ${ }^{2}$

The present results have confirmed the general features of the atomic arrangement reported in 1932 by Zachariasen and Ziegler. ${ }^{3}$

\section{EXPERIMENTAL}

Preparation of the crystals. When a water solution of sodium sulphate is evaporated above $32^{\circ} \mathrm{C}$, crystals of thenardite are formed (but below $32^{\circ} \mathrm{C} \mathrm{Na}_{2} \mathrm{SO}_{4} .10 \mathrm{H}_{2} \mathrm{O}$ crystals are obtained). There are several contradictory recommendations in the literature as to 
proper conditions for the evaporation process.1,2 A fairly quick evaporation overnight at $70^{\circ} \mathrm{C}$ gave the most well-developed crystals. This was the best result from a series of experiments. These crystals also gave the most distinct powder diffraction pattern. The sample contained small amounts of moisture; on ignition the loss of $\mathrm{H}_{2} \mathrm{O}$ was $0.14 \%$.

$X$-Ray powder diffraction data. The powder pattern of the sample was found to be in good accordance with the data given by Swanson and Fuyat." Values for the cell dimensions were calculated from a photograph taken with strictly monochromatized $\mathrm{CuK} \alpha_{1}$ radiation $(\lambda=1.54050 \AA)$ in a Guinier-Hägg type focusing camera. Potassium chloride $(a=6.29228 \AA)^{5}$ was used as an internal standard. The lattice parameters were

Table 1. X-Ray powder data for $\mathrm{Na}_{2} \mathrm{SO}_{4}(\mathrm{~V})$ at $25^{\circ} \mathrm{C} . \mathrm{CuK \alpha _{1 }}$ radiation $(\lambda=1.54050 \AA)$.

\begin{tabular}{|c|c|c|c|c|c|}
\hline$h k l$ & $\begin{array}{c}\sin ^{2} \theta \\
\text { obs }\end{array}$ & $\begin{array}{l}\sin ^{2} \theta \\
\text { calc }\end{array}$ & $I_{\text {obs }}$ & $\begin{array}{c}d(\AA) \\
\text { obs }\end{array}$ & $\begin{array}{c}d(\AA) \\
\text { calc }\end{array}$ \\
\hline 111 & 0.02736 & 0.02735 & 60 & 4.6567 & 4.6572 \\
\hline 022 & 0.04028 & 0.04030 & 16 & 3.8378 & 3.8369 \\
\hline 131 & 0.05873 & 0.05870 & 47 & 3.1784 & 3.1791 \\
\hline 040 & 0.06278 & 0.06270 & 41 & 3.0742 & 3.0761 \\
\hline 113 & 0.07660 & 0.07660 & 100 & 2.7830 & 2.7830 \\
\hline 220 & 0.08478 & 0.08479 & 45 & 2.6453 & 2.6452 \\
\hline 202 & 0.09370 & 0.09374 & 1 & 2.5163 & 2.5158 \\
\hline 004 & 0.09859 & 0.09850 & 1 & 2.4531 & 2.4542 \\
\hline 133 & 0.10799 & 0.10795 & 5 & 2.3439 & 2.3443 \\
\hline 222 & 0.10931 & 0.10940 & 22 & 2.3297 & 2.3287 \\
\hline 151 & 0.12142 & 0.12140 & 4 & 2.2105 & 2.2106 \\
\hline 044 & 0.16124 & 0.16120 & 4 & 1.9182 & 1.9185 \\
\hline 311 & 0.16562 & 0.16559 & 2 & 1.8927 & 1.8929 \\
\hline 153 & 0.17070 & 0.17065 & 47 & 1.8643 & 1.8646 \\
\hline 115 & 0.17508 & 0.17510 & 6 & 1.8408 & 1.8407 \\
\hline 224 & 0.18336 & 0.18330 & 6 & 1.7988 & 1.7991 \\
\hline 260 & 0.21026 & 0.21019 & 21 & 1.6798 & 1.6801 \\
\hline 313 & 0.21490 & 0.21484 & 12 & 1.6616 & 1.6618 \\
\hline 244 & 0.23030 & 0.23031 & 6 & 1.6050 & 1.6050 \\
\hline 262 & 0.23472 & 0.23481 & 3 & 1.5898 & 1.5895 \\
\hline 026 & 0.23732 & 0.23730 & 3 & 1.5811 & 1.5812 \\
\hline 333 & 0.24618 & 0.24619 & 20 & 1.5524 & 1.5524 \\
\hline 351 & 0.25967 & 0.25964 & 3 & 1.5116 & 1.5116 \\
\hline 173 & 0.26471 & 0.26470 & 10 & 1.4971 & 1.4971 \\
\hline 400 & 0.27651 & 0.27647 & 1 & 1.4648 & 1.4649 \\
\hline 206 & 0.29073 & 0.29074 & 11 & 1.4285 & 1.4285 \\
\hline 371 & 0.35370 & 0.35369 & 4 & 1.2951 & 1.2951 \\
\hline
\end{tabular}

refined from 27 reflections (Table 1) by the method of linear regression using the program POWDER. ${ }^{6}$ The dimensions of the orthorhombic unit cell (with standard deviations) at $25^{\circ} \mathrm{C}$ are:

$$
\begin{aligned}
& a=5.8596 \pm 5 \AA \\
& b=12.3044 \pm 12 \AA \\
& c=9.8170 \pm 10 \AA
\end{aligned}
$$

From X-ray photographic methods (oscillations and Weissenberg photographs around the $a$ and $c$ axes) the space group was, from the reflections systematically absent, uniquely determined as No. $70, F^{7} d d d^{7}$ in agreement with Zachariasen and Ziegler. The crystal selected for collection of X-ray data had the dimensions $0.15 \mathrm{~mm}$ (in the direction of the $c$ axis) $\times 0.06 \mathrm{~mm} \times 0.03 \mathrm{~mm}$ and was mounted along the $c$ axis. The $X$-ray intensity data were collected with $\theta-2 \theta$ scan technique on an automatic single-

Acta Chem. Scand. 27 (1973) No. 3 
crystal diffractometer Siemens AED (Automatischer Einkristall-Diffraktometer) equipped with a graphite monochromator and a scintillation detector. MoK$\alpha$ radiation was used. All independent reflections with $\theta \lesssim 50^{\circ}$ were measured at a temperature of $22^{\circ} \mathrm{C}$. Punched paper tape was used as input/output medium for the diffractometer. The computer programs used for the calculations involved in the present work are summarized in Table 9. A survey of the IBM $360 / 75$. programs used at this institute is also given in a paper by Brandt and Nord. ${ }^{8}$

All reflections with $\sigma\left(I_{\text {net }}\right) / I_{\text {nct }}<0.50$ were accepted leaving 812 reflections from about 900 measured ones. The net intensities were corrected for Lorentz, polarization and absorption $\left(\mu=10.3 \mathrm{~cm}^{-1}\right)$ effects.

\section{REFINEMENT OF THE CRYSTAL STRUCTURE}

All atom position parameters were readily determined from peaks in a three-dimensional Patterson function $P(u v w)$. These parameters agreed within a few per cent with those given by Zachariasen and Ziegler. The crystal structure was then refined by the full-matrix least-squares program LALS minimizing $\sum w\left(\left|F_{\text {obs }}\right|-\left|F_{\text {calc }}\right|\right)^{2}$. Hughes' weighting function ${ }^{9}$ with $h=4$ was used in the final refinements. The atomic scattering curves applied were those for $\mathrm{S}^{0}, \mathrm{Na}^{+}$, and $\mathrm{O}^{-}$. Correction was made for the real part of the anomalous dispersion. After a few cycles with isotropic temperature factors the reliability index $R=\sum|| F_{\text {obs }}|-| F_{\text {calc }}|| / \sum\left|F_{\text {obs }}\right|$ dropped to $5.0 \%$. When all atoms in the model were allowed to vibrate anisotropically (within the restrictions fixed by the space group symmetry) the final $R$ was reduced to $3.6 \%$ for all 812 reflections. This large drop in weighted and unweighted $R$ values from the isotropically to the anisotropically refined model enables the Hamilton test ${ }^{10}$ to show, that the model with anisotropically vibrating atoms is the more realistic one. The weighting scheme obtained in the final cycle of the anistropic refinement is shown in Table 2. Reflections with $1.20<\left|F_{\text {obs }}\right| F_{\text {calc }} \mid<0.70$ were given zero weight in the refinement.

A list of the observed and calculated structure factors is presented in Table 3. The atomic parameters arrived at in the last cycle of anisotropic refinement are listed in Table 4. The temperature factors obtained in the

Table 2. Weight analysis obtained in the final cyele of the anisotropic least-squares refinement of thenardite. $w=$ weighting factor, $\Delta=|| F_{\text {obs }}|-| F_{\text {calc }} \mid l$.

\begin{tabular}{cccccc}
\hline $\begin{array}{c}\text { Interval } \\
F_{\text {obs }}\end{array}$ & $\overline{w \Delta^{2}}$ & $\begin{array}{c}\text { Number of } \\
\text { independent } \\
\text { reflections }\end{array}$ & $\begin{array}{c}\text { Interval } \\
\text { sin } \theta\end{array}$ & $\overline{w \Delta^{2}}$ & $\begin{array}{c}\text { Number of } \\
\text { independent } \\
\text { reflections }\end{array}$ \\
\hline $0.0-7.4$ & 1.08 & 75 & $0.000-0.362$ & 1.35 & 84 \\
$7.4-9.3$ & 1.15 & 76 & $0.362-0.456$ & 1.31 & 93 \\
$9.3-11.5$ & 1.08 & 76 & $0.456-0.522$ & 1.11 & 81 \\
$11.5-13.6$ & 0.91 & 75 & $0.522-0.575$ & 0.96 & 85 \\
$13.6-16.5$ & 0.88 & 77 & $0.575-0.619$ & 0.88 & 81 \\
$16.5-20.3$ & 0.90 & 75 & $0.619-0.658$ & 0.77 & 82 \\
$20.3-26.4$ & 0.86 & 75 & $0.658-0.693$ & 0.85 & 70 \\
$26.4-35.9$ & 1.31 & 74 & $0.693-0.724$ & 0.97 & 66 \\
$35.9-51.8$ & 0.97 & 75 & $0.724-0.753$ & 0.81 & 68 \\
$51.8-206.1$ & 0.87 & 76 & $0.753-0.780$ & 0.72 & 44 \\
\hline
\end{tabular}


Table 3. Observed and calculated structure factors of thenardite, $\mathrm{Na}_{2} \mathrm{SO}_{4}(\mathrm{~V})$.

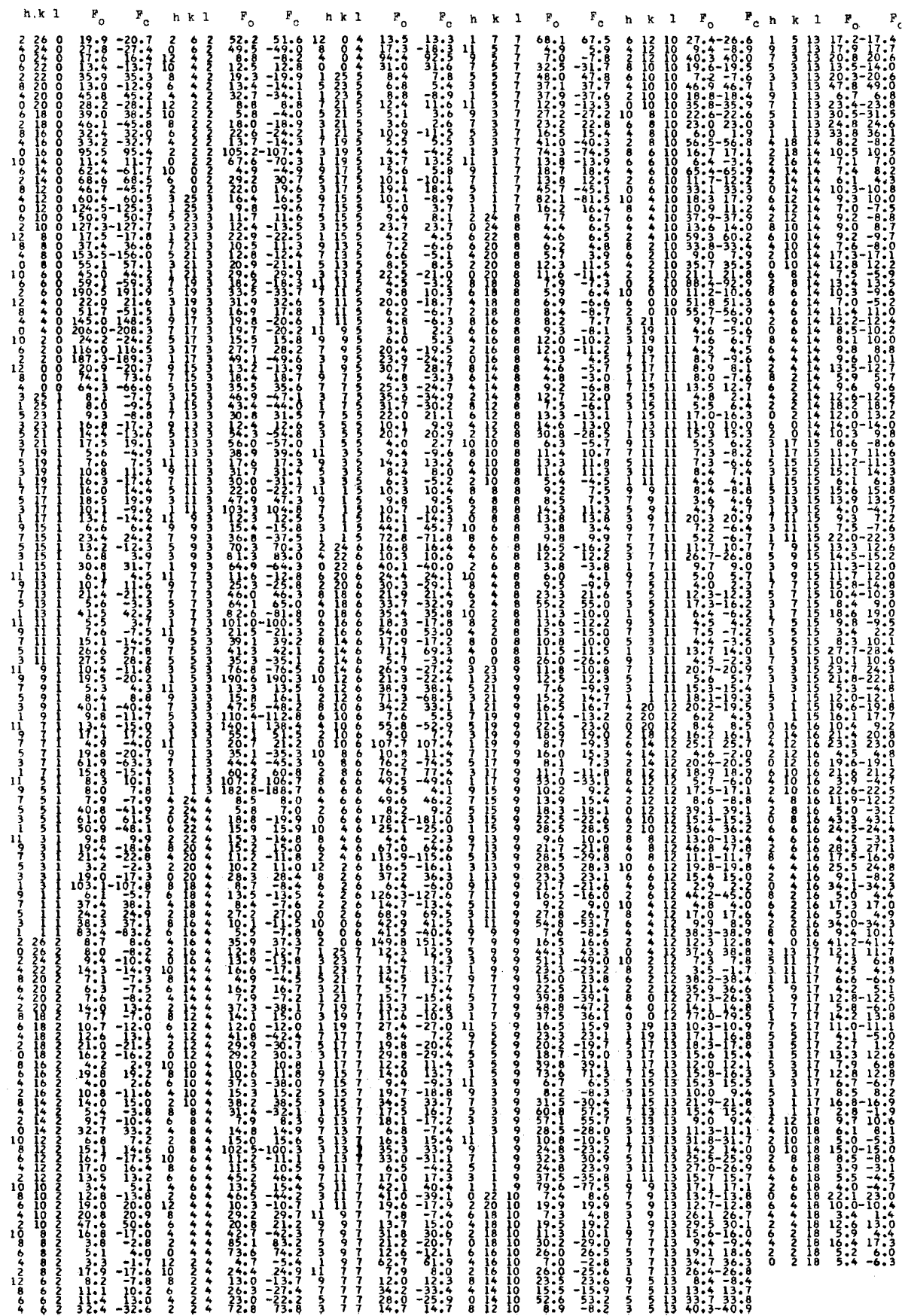


Table 4. The crystal structure of $\mathrm{Na}_{2} \mathrm{SO}_{4}(\mathrm{~V})$, thenardite.

Space group: (No. 70) Fddd.

Unit cell dimensions: $a=5.8596 \pm 5 \AA$

$b=12.3044 \mp 12 \AA$

$c=9.8170 \pm 10 \AA$

$V=707.8 \AA^{3} . D_{\text {calc }}=2.666 \mathrm{~g} / \mathrm{cm}^{3}, D_{\text {obs }}=2.65 \mathrm{~g} / \mathrm{cm}^{3}$.

Cell content: $8 \mathrm{Na}_{2} \mathrm{SO}_{4}$.

Arrangement of atoms ( $f$ denotes translations characteristic of a face centered lattice):

$8 \mathrm{~S}$ in $8(a): \quad \pm\left(\frac{1}{8}, \frac{1}{8}, \frac{1}{8}\right)_{\mathrm{f}}$

$16 \mathrm{Na}$ in $16(g): \quad \pm\left(\frac{1}{8}, \frac{1}{8}, z\right)_{\mathrm{f}}, \pm\left(\frac{1}{8}, \frac{1}{8}, \frac{1}{4}-z\right)_{\mathrm{f}}$

$32 \mathrm{O}$ in $32(h): \quad \pm(x, y, z)_{\mathrm{f}}, \pm\left(\mathrm{x}, \frac{1}{4}-y, 1-z\right)_{\mathrm{f}}, \pm\left(\frac{1}{4}-x, y, 1-z\right)_{\mathrm{f}} \pm\left(\frac{1}{4}-x, 1-y, z\right)_{\mathrm{f}}$

Fractional atomic coordinates

\begin{tabular}{|c|c|c|c|c|c|c|}
\hline Atom & & $x \pm \sigma(x)$ & & $y \pm \sigma(y)$ & \multicolumn{2}{|c|}{$z \pm \sigma(z)$} \\
\hline $\begin{array}{l}\mathrm{S} \\
\mathrm{Na} \\
\mathrm{O}\end{array}$ & & $\begin{array}{c}\frac{1}{8} \\
\frac{1}{8} \\
-0.0203 \pm 2\end{array}$ & & $0.0572 \pm 1$ & \multicolumn{2}{|c|}{$\begin{array}{l}\frac{1}{8} \\
0.4414 \pm 1 \\
0.2137 \pm 1\end{array}$} \\
\hline \multicolumn{7}{|c|}{$\begin{array}{l}\text { Anisotropic thermal parameters }\left(\times 10^{5}\right) \\
\qquad T=\exp \left[-\left(B_{11} h^{2}+B_{22} k^{2}+B_{33} l^{2}+B_{12} h k+B_{13} h l+B_{23} k l\right)\right]\end{array}$} \\
\hline Atom & $B_{11}$ & $B_{22}$ & $B_{33}$ & $B_{12}$ & $B_{13}$ & $B_{23}$ \\
\hline $\begin{array}{l}\mathrm{S} \\
\mathrm{Na} \\
\mathrm{O}\end{array}$ & $\begin{array}{r}518 \pm 6 \\
926 \pm 11 \\
1041 \pm 12\end{array}$ & $\begin{array}{l}113 \pm 2 \\
192 \pm 3 \\
207 \pm 3\end{array}$ & $\begin{array}{l}206 \pm 3 \\
432 \pm 5 \\
345 \pm 5\end{array}$ & $\begin{array}{r}0 \\
35 \pm 8 \\
-297 \pm 10\end{array}$ & $\begin{array}{l}0 \\
0 \\
319 \pm 12\end{array}$ & $\begin{array}{c}0 \\
0 \\
65 \pm 5\end{array}$ \\
\hline
\end{tabular}

isotropic refinement were $B_{\mathrm{S}}=0.74 \pm 0.01, B_{\mathrm{Na}}=1.30 \pm 0.02, B_{\mathrm{O}}=1.29 \pm 0.02 \AA^{2}$. A three-dimensional $\Delta F$ Fourier synthesis was then computed with the anisotropic model. This showed no peak or hole greater than $0.6 \mathrm{e}^{-3}$. A close inspection of Table 3 shows that the extinction effects are so small that they are negligible.

\section{DESCRIPTION AND DISCUSSION OF THE CRYSTAL STRUCTURE}

The crystal structure may be described in terms of nearly regular $\mathrm{SO}_{4}$ tetrahedra and distorted $\mathrm{NaO}_{6}$ octahedra. In fact, the $\mathrm{NaO}_{6}$ octahedra are more distorted than Zachariasen and Ziegler reported. The interatomic distances and standard deviations $(\sigma)$ and some angles of interest are listed in Table 5. No corrections have been made for the thermal vibration.

The sodium atoms are each surrounded by 6 oxygen atoms, two at $2.334 \AA$, two at $2.426 \AA$, and two at $2.534 \AA$, forming distorted $\mathrm{NaO}_{6}$ octahedra with a 2-fold axis parallel to the $c$ axis. These $\mathrm{Na}-\mathrm{O}$ distances are quite in accordance with those reported in other compounds, e.g. $\mathrm{Na}_{2} \mathrm{SO}_{4} 10 \mathrm{H}_{2} \mathrm{O} .^{11}$ All the sulphate ions are separated from each other by distances $>3 \AA$ for two oxygen 
Table 5. Interatomic distances $(\AA)$ with standard deviations and some angles in $\mathrm{Na}_{2} \mathrm{SO}_{4}(\mathrm{~V})$. All angles have standard deviations of $\pm 0.05^{\circ}$ or less. No corrections have been made for thermal vibration. Atom denotations used in Table 5, Table 7, and Fig. 2: $\mathrm{S}, \mathrm{Na}$, and $\mathrm{O}(1)$ in $(x, y, z), \mathrm{O}(2):\left(x, \frac{1}{4}-y, \frac{1}{4}-z\right), \mathrm{O}(3):\left(\frac{1}{4}-x, y, \frac{1}{4}-z\right), \mathrm{O}(4):\left(\frac{1}{4}-x, \frac{1}{4}-y, z\right)$, $\mathrm{O}(5):\left(\frac{1}{2}+x, \frac{1}{4}-y, \frac{3}{4}-z\right), \mathrm{O}(6):\left(\frac{1}{4}+x,-y, \frac{1}{4}+z\right), \mathrm{O}(7):\left(-\frac{1}{4}-x, y, \frac{3}{4}-z\right), \mathrm{O}(8):(-x$, $1+y, 1+z)$. Oxygen-oxygen edges shared by $\mathrm{SO}_{4}$ and $\mathrm{NaO}_{6}$ are marked $\left({ }^{*}\right)$.

\begin{tabular}{lllll}
\hline $\mathrm{SO}_{4}$ group & $\mathrm{S}-\mathrm{O}(1,2,3,4)$ & $1.476 \pm 1$ & $\mathrm{O}(1)-\mathrm{S}-\mathrm{O}(2)$ & $109.55^{\circ}$ \\
& $\mathrm{O}(1)-\mathrm{O}(2)$ & $2.412 \pm 2$ & $\mathrm{O}(1)-\mathrm{S}-\mathrm{O}(3)$ & $111.15^{\circ}$ \\
& $\mathrm{O}(1)-\mathrm{O}(3)$ & $2.435 \pm 2$ & $\mathrm{O}(1)-\mathrm{S}-\mathrm{O}(4)$ & $107.74^{\circ}$ \\
& $\mathrm{O}(1)-\mathrm{O}(4)^{*}$ & $2.384 \pm 2$ & Average: & $109.48^{\circ}$ \\
$\mathrm{NaO}_{6}$ group & & & \\
& $\mathrm{Na}-\mathrm{O}(1,4)$ & $2.534 \pm 1$ & $\mathrm{O}(1)-\mathrm{Na}-\mathrm{O}(4)$ & $56.13^{\circ}$ \\
& $\mathrm{Na}-\mathrm{O}(5,7)$ & $2.426 \pm 1$ & $\mathrm{O}(1)-\mathrm{Na}-\mathrm{O}(6)$ & $81.64^{\circ}$ \\
& $\mathrm{Na}-\mathrm{O}(6,8)$ & $2.334 \pm 1$ & $\mathrm{O}(6)-\mathrm{Na}-\mathrm{O}(7)$ & $81.89^{\circ}$ \\
& $\mathrm{O}(1)-\mathrm{O}(4)^{*}$ & $2.384 \pm 2$ & $\mathrm{O}(1)-\mathrm{Na}-\mathrm{O}(7)$ & $86.43^{\circ}$ \\
$\mathrm{O}(6)-\mathrm{O}(7)$ & $3.120 \pm 2$ & $\mathrm{O}(1)-\mathrm{Na}-\mathrm{O}(8)$ & $93.97^{\circ}$ \\
$\mathrm{O}(1)-\mathrm{O}(6)$ & $3.186 \pm 2$ & $\mathrm{O}(5)-\mathrm{Na}-\mathrm{O}(8)$ & $108.09^{\circ}$ \\
$\mathrm{O}(1)-\mathrm{O}(7)$ & $3.397 \pm 2$ & $\mathrm{O}(1)-\mathrm{Na}-\mathrm{O}(5)$ & $134.82^{\circ}$ \\
$\mathrm{O}(7)-\mathrm{O}(8)$ & $3.481 \pm 2$ & $\mathrm{O}(6)-\mathrm{Na}-\mathrm{O}(8)$ & $169.27^{\circ}$ \\
$\mathrm{O}(1)-\mathrm{O}(8)$ & $3.942 \pm 2$ & & \\
$\mathrm{O}(5)-\mathrm{O}(7)$ & $4.479 \pm 2$ & & \\
$\mathrm{O}(1)-\mathrm{O}(5)$ & $4.626 \pm 2$ & & \\
$\mathrm{O}(6)-\mathrm{O}(8)$ & $4.648 \pm 2$ & & \\
\hline
\end{tabular}

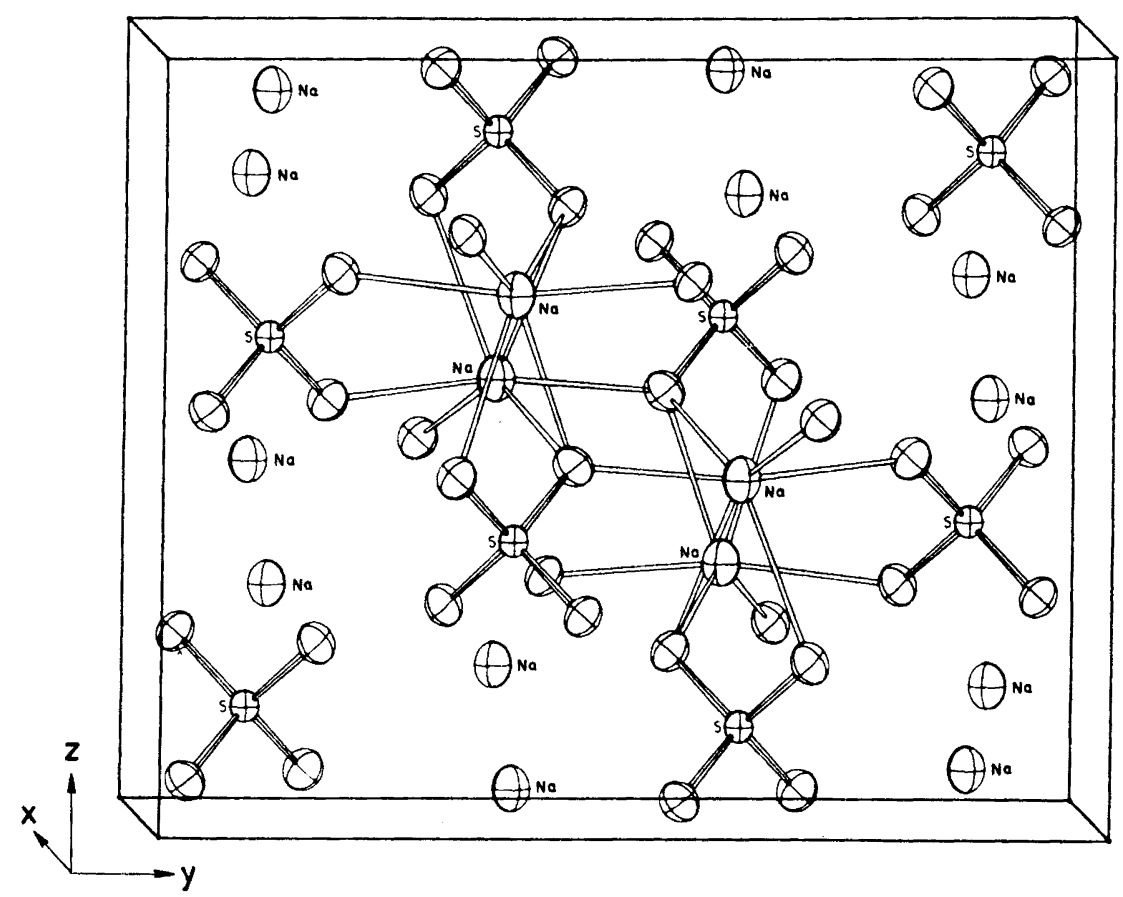

Fig. 1. The crystal structure of thenardite. One unit cell with eight sulphate ions and four $\mathrm{NaO}_{6}$ octahedra is shown.

Acta Chem. Scand. 27 (1973) No. 3 
atoms belonging to different sulphate groups (Table 5). The $\mathrm{SO}_{4}$ tetrahedra are nearly regular. All $\mathrm{S}-\mathrm{O}$ distances are equal, $1.476 \pm 0.001 \AA$, due to the space group since the sulphur atom is fixed in a special point position with 222 point symmetry. Each $\mathrm{SO}_{4}$ tetrahedron shares two of its edges with two different $\mathrm{NaO}_{6}$ octahedra. The longest $\mathrm{Na}-\mathrm{O}$ distance of $2.534 \AA$ represents the distances to oxygens forming the shared tetrahedral edge. The remaining corners of the $\mathrm{NaO}_{6}$ octahedron are shared with another four $\mathrm{SO}_{4}$ tetrahedra thus giving a three-dimensional framework. Fig. 1 shows a threedimensional model of the crystal structure. It has been produced by the plot program ORTEP. ${ }^{12}$ Fig. 2 is an ORTEP plot picture showing one $\mathrm{NaO}_{6}$ octahedron.

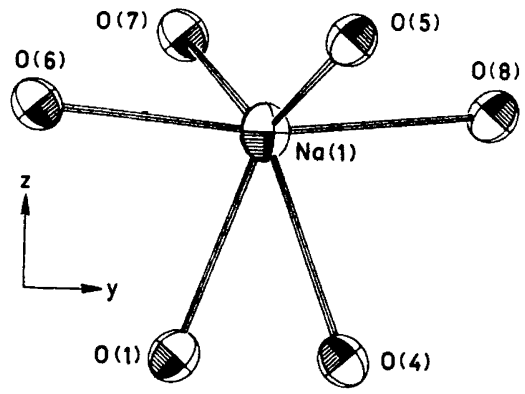

Fig. 2. One $\mathrm{NaO}_{6}$ octahedron showing the coordination of oxygen atoms around a sodium atom in thenardite. The atoms have been numbered as in Tables 5 and 7 .

Table 6. Analysis of anisotropic thermal parameters.

\begin{tabular}{cccc}
\hline Atom & Axis & $\begin{array}{c}\text { Root of mean square } \\
\text { amplitude }(\AA)\end{array}$ & $\begin{array}{c}\text { R.m.s. radial } \\
\text { thermal displace- } \\
\text { ment }(\AA)\end{array}$ \\
\hline & 1 & 0.093 & \\
$\mathrm{~S}$ & 2 & 0.095 & \\
& 3 & 0.100 & 0.228 \\
$\mathrm{Na}$ & 2 & 0.120 & \\
& 3 & 0.128 & 0.226 \\
\hline
\end{tabular}

Table 7. Some interatomic distances $(\AA)$ in thenardite.

\begin{tabular}{lcc}
\hline & Uncorrected & "Independent" \\
\hline $\mathrm{S}-\mathrm{O}(1,2,3,4)$ & 1.476 & 1.497 \\
$\mathrm{O}(1)-\mathrm{O}(2), \mathrm{O}(3)-\mathrm{O}(4)$ & 2.412 & 2.427 \\
$\mathrm{O}(1)-\mathrm{O}(3), \mathrm{O}(2)-\mathrm{O}(4)$ & 2.435 & 2.451 \\
$\mathrm{O}(1)-\mathrm{O}(4), \mathrm{O}(2)-\mathrm{O}(3)$ & 2.384 & 2.401 \\
$\mathrm{Na}-\mathrm{O}(1)$ & 2.534 & 2.546 \\
$\mathrm{Na}-\mathrm{O}(5)$ & 2.426 & 2.440 \\
$\mathrm{Na}-\mathrm{O}(6)$ & 2.334 & 2.350 \\
\hline
\end{tabular}


Table 8. Data for sulphate groups. Uncorrected and corrected S-O bond distances (in $\AA$ ) are given for six carefully determined sulphate structures. The corrected distances have all been calculated in the same manner, i.e. assuming the riding motion model.

\begin{tabular}{|c|c|c|c|c|c|c|}
\hline $\begin{array}{l}\text { Compound: } \\
\text { Ref.: }\end{array}$ & $\begin{array}{c}\mathrm{Na}_{2} \mathrm{SO}_{4}(\mathrm{~V}) \\
\text { This work }\end{array}$ & $\underset{\text { Larson }}{\mathrm{Li}_{2} \mathrm{SO}_{4} \cdot \mathrm{H}_{2} \mathrm{O}}$ & $\underset{\text { Baur }{ }^{15}}{\mathrm{MgSO}_{4} .4 \mathrm{H}_{2} \mathrm{O}}$ & 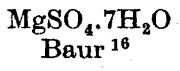 & $\underset{\text { Baur }{ }^{17}}{\mathrm{FeSO}_{4} \cdot 7 \mathrm{H}_{2} \mathrm{O}}$ & $\underset{\text { MeGinnety }}{\beta-\mathrm{K}_{2} \mathrm{SO}_{4}}$ \\
\hline $\begin{array}{l}\text { Uncorr. } \\
\text { bond dist. } \\
\text { Shortest } \\
\text { Longest } \\
\text { Average }\end{array}$ & $\begin{array}{l}1.476 \pm 1 \\
1.476 \pm 1 \\
1.476\end{array}$ & $\begin{array}{l}1.462 \pm 2 \\
1.482 \pm 2 \\
1.472\end{array}$ & $\begin{array}{l}1.466 \pm 5 \\
1.480 \pm 4 \\
1.473\end{array}$ & $\begin{array}{l}1.460 \pm 4 \\
1.482 \pm 4 \\
1.471\end{array}$ & $\begin{array}{l}1.462 \pm 4 \\
1.488 \pm 4 \\
1.474\end{array}$ & $\begin{array}{l}1.459 \pm 4 \\
1.473 \pm 4 \\
1.469\end{array}$ \\
\hline $\begin{array}{l}\text { Corrected } \\
\text { bond dist. } \\
\text { Average }\end{array}$ & 1.484 & 1.480 & 1.479 & 1.486 & 1.486 & 1.486 \\
\hline
\end{tabular}

Table 9. Computer programs used for the crystallographic calculations. All programs are written in FORTRAN IV for an IBM $360 / 75$ computer except program SIMSA.

Program name and function

1. LAZY. Calculation of $\sin ^{2} \theta$ - and $d$-values from a Guinier powder photograph after internal standard correction.

2. POWDER. Refinement of cell constants. Ref. 6.

3. SIP. Generation of steering paper tape for Siemens AED.

4. SIMSA. Interpretation and evaluation of paper tape output from Siemens AED. IBM 1800 .

5. DATAP2. Lp- and absorption correction.

6. DRF. Fourier summations and structure factor calculations.

7. LALS. Full matrix least squares refinement of positional and thermal parameters.

8. DISTAN. Calculation of interatomic distances and bond angles with e.s.d.

9. ORFFE. Crystallographic function and error program. Ref. 13.

10. ORTEP. Thermal ellipsoid plot program for crystal structure illustrations. Ref. 12.
Authors

A. G. Nord, Stockholm, Sweden.

O. Lindqvist and F. Wengelin, Göteborg. Modified by A. G. Nord and B. G. Brandt, Stockholm, Sweden.

R. Norrestam, Stockholm, Sweden.

R. Norrestam, Stockholm, Sweden.

P. Coppens, L. Leiserowitz and D. Rabinovich, Rehovath, Israel. Modified by O. Olofsson and M. Elfström, Uppsala. Further modifications by S. Asbrink, B. G. Brandt and A. G. Nord, Stockholm, Sweden.

A. Zalkin, Berkeley, USA. Local modification.

P. K. Gantzel, R. A. Sparks, and K. N. Trueblood, Los Angeles, USA. Modified by A. Zalkin, J. O. Lundgren, R. Liminga, C. I. Brändén, A. G. Nord and B. G.Brandt. A. Zalkin, Berkeley, USA. Local modification.

W. R. Busing, K. O. Martin, and H. A. Levy, Oak Ridge, USA. Modified by L. Kihlborg, Stockholm, Sweden.

C. K. Johnsson, Oak Ridge, USA.

Acta Chem. Scand: 27 (1973) No. 3 
The anisotropic thermal parameters were analysed to find the axes of the ellipsoids. Some results from program ORFFE are presented in Table 6. The character of thermal vibration may also be studied in Figs. 1-2. Table 7 contains some bond lengths in thenardite corrected due to thermal motion. The effect of thermal motion on the distances is calculated assuming the "independent motion" model. ${ }^{13}$

Pertinent data relating to the sulphate group in some compounds are given in Table 8. All "corrected" $\mathrm{S}-\mathrm{O}$ distances have been calculated in the same manner, i.e. assuming the "riding motion" model. ${ }^{13}$ Although the ligand atoms of the different sulphate groups vary, all uncorrected $\mathrm{S}-\mathrm{O}$ distances as well as all corrected ones are nearly identical. The $\mathrm{S}-\mathrm{O}$ distances within each sulphate group are also very similar, but the differences exceed the reported standard deviations. However, all these facts show that the sulphate ion in the compounds discussed is fairly stable and it also possesses a high degree of regularity.

Acknowledgements. The author thanks Professors Peder Kierkegaard and Arne Magnéli for their active and stimulating interest in this work. Thanks are also due to Dr. B. G. Gäfvert for revising the English of this paper. The work has been supported by the Swedish Natural Science Research Council.

\section{REFERENCES}

1. Gmelin, Handbuch der anorganischen Chemie $21: 3$ (1966) 1091.

2. Kracek, F. C. J. Phys. Chem. 33 (1929) 1281.

3. Zachariasen, W. H. and Ziegler, G. E. Z. Krist. 81 (1932) 92.

4. Swanson, H. E. and Fuyat, R. K. Natl. Bur. Std. U.S. Circ. 539:2 (1953) 59.

5. Hambling, P. G. Acta Cryst. 6 (1953) 98.

6. Lindqvist, O. and Wengelin, F. Arkiv Kemi 28 (1967) 179.

7. International Tables for X-Ray Crystallography, Kynoch Press, Birmingham 1962, Vol. I.

8. Brandt, B. G. and Nord, A. G. Chem. Commun. Univ. Stockholm (1970) No. V.

9. Hughes, E. W. J. Am. Chem. Soc. 63 (1941) 1737.

10. Hamilton, W. C. Acta Cryst. 18 (1965) 502.

11. Ruben, H. W., Templeton, D. H., Rosenstein, R. D. and Olovsson, I. J. Am. Chem. Soc. 83 (1961) 820.

12. Johnson, C. K. AEC Accession No. 33516, ORNL-3794, Oak Ridge National Laboratory, U.S.A. 1965.

13. Busing, W. R. and Levy, H. A. Acta Cryst. 17 (1964) 142.

14. Larson, A. C. Acta Cryst. 18 (1965) 717.

15. Baur, W. H. Acta Cryst. 17 (1964) 863.

16. Baur, W. H. Acta Cryst. 17 (1964) 1361.

17. Baur, W. H. Acta Cryst. 17 (1964) 1167.

18. McGinnety, J. A. Acta Cryst. B 28 (1972) 2845. 